Pesq. Vet. Bras. 36(6):468-472, junho 2016

DOI: $10.1590 / \mathrm{S} 0100-736 \mathrm{X} 2016000600002$

\title{
Swinepox dermatitis in backyard pigs in Northeastern Brazil ${ }^{1}$
}

\author{
Roberio G. Olinda ${ }^{2 *}$, Lisanka A. Maia², Juliana F. Cargnelutti ${ }^{3}$, Rayr C.S. Gois ${ }^{4}$, Jael S. \\ Batista $^{4}$, Antônio F.M. Dantas ${ }^{2}$, Eduardo F. Flores ${ }^{3}$ and Franklin Riet-Correa ${ }^{2}$
}

\begin{abstract}
Olinda R.G., Maia L.A., Cargnelutti J.F., Gois R.C.S., Batista J.S., Dantas A.F.M., Flores E.F. \& Riet-Correa F. 2016. Swinepox dermatitis in backyard pigs in Northeastern Brazil. Pesquisa Veterinária Brasileira 36(6):468-472. Programa de Pós-Graduação em Medicina Veterinária, Hospital Veterinário, Centro de Saúde e Tecnologia Rural, Universidade Federal de Campina Grande, Campus de Patos, Patos, PB 58700-000, Brazil. E-mail: rgumes@hotmail.com

This article describes five outbreaks of swinepox in backyard pigs in Northeastern Brazil. It affected backyard pigs from herds of poor hygienic-sanitary conditions with severe fly and lice infestations. The morbidity ranged from 33.3 to $100 \%$ among affected herds, with mortality reaching up to $60 \%$. The affected pigs developed multifocal to coalescent gray to white papules and blisters in the skin, with eventual eruptions, evolving to erosions and crusts. In addition to skin lesions, affected piglets presented apathy, anorexia and fever. The disease was auto-limiting, resolving within 15 to 25 days. Histological examination revealed proliferative and ulcerative vesiculopustular dermatitis with ballooning degeneration of epithelial cells, perivascular inflammatory infiltrates of lymphocytes, plasma cells, neutrophils, eosinophils and some macrophages in the dermis. Intracytoplasmic eosinophilic inclusions were consistently observed in keratinocytes. Total DNA extracted from fresh tissue fragments obtained from one outbreak and formalin-fixed, paraffin-embedded (FFPE) tissue from the other four outbreaks was submitted to polymerase chain reaction (PCR) for Swinepox virus (SWPV) and Vaccinia virus (VACV). Genetic SWPV material was identified by PCR in fresh material from one outbreak. Nucleotide sequencing and phylogenetic analysis of the PCR amplicons (viral polymerase gene) demonstrated 100\% homology with sequences from SWPV. All tissues were PCR negative for VACV. Swine poxvirus is present in backyard pigs in Northeastern Brazil, indicating the need of including SWPV in the differential diagnosis of dermatitis in pigs.
\end{abstract}

INDEX TERMS: Swine, poxvirus, dermatitis, viral disease.

RESUMO.- [Varíola em suínos no Nordeste do Brasil.] Em cinco surtos de varíola em suínos no Nordeste do Brasil foram acometidos leitões e suínos adultos, de rebanhos domésticos criados em condições higiênico-sanitárias pre-

\footnotetext{
${ }^{1}$ Received on June 11, 2015.

Accepted for publication on March 23, 2016.

${ }^{2}$ Programa de Pós-Graduação, em Medicina Veterinária, Hospital Veterinário, Centro de Saúde e Tecnologia Rural, Universidade Federal de Campina Grande (UFCG), Campus de Patos, Patos, PB 58700-000, Brazil. *Corresponding author: rgumes@hotmail.com

${ }^{3}$ Setor de Virologia, Departamento de Medicina Veterinária Preventiva, Universidade Federal de Santa Maria (UFSM), Av. Roraima 1000, Santa Maria, RS 97105-900, Brazil.

${ }^{4}$ Laboratório de Patologia Animal, Departamento de Ciências Animais, Universidade Federal Rural do Semi-Árido, Av. Francisco Mota 572, Presidente Costa e Silva, Mossoró, RN 59625-900, Brazil.
}

cárias, que apresentavam graves infestações por moscas e piolhos. A morbidade variou de $33,3-100 \%$ entre os rebanhos afetados e a mortalidade atingindo $60 \%$. Os animais afetados desenvolveram pápulas cinzentas ou esbranquiçadas coalescentes e vesículas, que evoluíram para erosões e crostras. Além das lesões de pele, os leitões afetados apresentavam apatia, anorexia e febre. A doença foi autolimitante, com resolução em 15 a 25 dias. Histologicamente, observou-se dermatite proliferativa e ulcerativa com degeneração balonosa das células do epitélio, infiltrado inflamatório perivascular de linfócitos, plasmócitos, neutrófilos, eosinófilos e escassos macrófagos na derme. Inclusões eosinofílicas intracitoplasmáticas foram consistentemente observadas em queratinócitos. DNA total extraído a partir de fragmentos de tecido frescos obtidos a partir de um surto, e de tecido fixado em formol e embebido em parafina 
dos outros quatro surtos, foram submetidos à reação em cadeia da polimerase (PCR) para o vírus da varíola suína (SWPV) e o vírus vaccínia (VACV). Material genético do SWPV foi identificado por PCR em material fresco de um surto. 0 sequenciamento e análise filogenética dos produtos de amplificação da PCR (gene da polimerase viral) demonstraram $100 \%$ de homologia com sequências do SWPV. Todos os fragmentos de tecidos foram negativos para VACV na PCR. Este artigo relata a circulação de poxvírus suíno no Nordeste do Brasil, indicando a necessidade de incluir SWPV no diagnóstico diferencial de dermatite em suínos.

TERMOS DE INDEXAÇÃO: Suíno, varíola, dermatite, doença viral.

\section{INTRODUCTION}

Swinepox is a vesiculopustular disease of young and adult pigs caused by Swinepox virus (family Poxviridae, genus Suipoxvirus) (Afonso et al. 2002). Affected pigs present progressive and frequently generalized lesions in the skin, starting with petechiae. These petechiae evolve through the stages of papules, vesicles and yellow pustules that eventually originate crusts (scabs) with crateriform aspect (Munz \& Dumbell 1994). The clinical course is approximately four weeks, but lesions may persist longer in pigs under poor hygienic conditions due to secondary bacterial and parasitic infections (Bersano et al. 2003, Medaglia et al. 2011).

Pigs are apparently the only host species of SWPV in nature and virus transmission is usually associated with poor hygienic conditions and the presence of insects, mainly lice (Haematopinus suis) and domestic flies (Musca domesti$\mathrm{ca}$ ) which act as mechanic vectors for virus transmission (Munz \& Dumbell 1994). The virus is usually transmitted by direct or indirect contact. Congenital infection resulting in newborn piglets with generalized lesions may sporadically occur (Paton et al. 1990). Although the mortality is generally low, the morbidity in affected herds may reach up to $100 \%$. Piglets are most frequently affected and present more severe lesions than adult animals (Bersano et al. 2003). In general, the disease is restricted to the skin, with preference to less keratinized regions such as flanks, abdomen, hears and internal face of the limbs (Jubb et al. 1992).

In Brazil, a number of studies have reported the occurrence of poxvirus-associated disease in livestock, including VACV (Sant'Ana et al. 2013), pseudocowpoxvirus and papular stomatitis virus infection in cattle (Cargnelutti et al. 2014). Swinepox may be confused with a condition caused by Vaccinia virus (VACV), which courses with a very similar clinical presentation in pigs (Schwarte \& Biester 1941, Delhon et al. 2007). Although swinepox infection has been reported in Brazil (Bersano et al. 2003, Medaglia et al. 2011), little epidemiological and clinical information on this disease is yet available. The objective of this article is to describe outbreaks of swinepox in the semi-arid Northeastern Brazilian region, in their epidemiological, clinico-pathological and etiological aspects.

\section{MATERIALS AND METHODS}

Five outbreaks of swinepox dermatitis in backyard pig herds of Rio Grande do Norte (RN) state are described. Epidemiological data collected from these outbreaks, including breed, age, morbidity and mortality are presented in Table 1.

Fragments of skin with lesions collected from outbreaks 1, 2, 3 and 5 were fixed in $10 \%$ buffered formalin, routinely processed, sectioned at $5 \mu \mathrm{m}$ and stained by hematoxylin and eosin (HE) for histopathology. Skin fragments of vesicles (outbreak 5) were submitted to virus isolation in porcine kidney cells (PK-15) and/or molecular detection (PCR) for SWPV and VACV.

Total DNA extracted from tissue fragments by phenol-chloroform was eluted in ultrapure water and used as template in a PCR that amplifies a $543 \mathrm{bp}$ of the SWPV DNA polymerase gene, as previously described (Bracht et al. 2006). The DNA was also submitted to a PCR for a $400 \mathrm{pb}$ region of gene $\mathrm{vgf}$ of VACV (Abrahão et al. 2010a). The Kasza strain of SWPV (kindly provided by Dra. Clarissa Damaso, Universidade Federal do Rio de Janeiro, UFRJ) and VACV isolate Pelotas 1 were used as positive controls (Campos et al. 2011). The amplicons of positive samples were purified ${ }^{a}$ and submitted to nucleotide sequencing ${ }^{\mathrm{b}}$.

The sequences were analysed by the program Staden Package (Staden 1996) and aligned by the software BioEdit (http://www. mbio.ncsu.edu/bioedit/bioedit.html) and compared to sequences of poxviruses deposited on GenBank to verify nucleotide identity and genetic relationships.

A phylogenetic tree was constructed based on the nucleotide sequence of the viral DNA polymerase gene of the amplified samples (SV627/14 A and B) and from poxviruses belonging to all genus (Fig.1). The tree was constructed using the program MEGA 5.0 (Tamura et al. 2011), using the Neighbor-Joining method with bootstrap of 1000 replicates; the evolutionary distances were calculated using the $p$-distance method.

\section{RESULTS}

The outbreaks were diagnosed in five backyard pig herds of two municipalities (Jucurutu, located at $S 6^{\circ} 02^{\prime} 02^{\prime \prime}$ and W $37^{\circ} 01^{\prime} 12^{\prime \prime}$, and Felipe Guerra, located at $S 5^{\circ} 36^{\prime} 10^{\prime \prime}$ and W $37^{\circ} 41^{\prime} 20^{\prime \prime}$ ) of Rio Grande do Norte state, Northeast Brazil from 2008 to 2014. In all farms, the pigs were raised in collective stalls, in full-cycle systems, without biosecurity measures. The food consisted of corn bran and garbage, and the pigs had contact with ruminants. The lesions were

\footnotetext{
${ }^{a}$ PureLink quick gel extraction and PCR purification combo kit (Invitrogen); Life Technologies, CA. ${ }^{\mathrm{b}}$ ABI-PRISM 3100 genetic analyzer (Applied Biosystems); Life Technologies, CA, USA.
}

Table 1. Epidemiological data of swinepox outbreaks in backyard pigs in Rio Grande do Norte state, Brazil

\begin{tabular}{cccccccc}
\hline Outbreak & Municipality & Month/year & Breed & Age & Number & Morbidity (\%) & Mortality (\%) \\
\hline 1 & Jucurutu & August/2008 & Landrace cross bred & $2-6$ month-old & 20 & 100 & 0 \\
2 & Felipe Guerra & July/2013 & Landrace cross bred & $1-8$ month-old & 40 & 100 & 60 \\
3 & Felipe Guerra & July/2013 & Cross bred & $4-6$ month-old & 30 & 33.3 & 0 \\
4 & Felipe Guerra & July/2013 & Cross bred & $1-20$ months & 35 & 65.7 & 55.5 \\
5 & Jucurutu & August/2014 & Large White cross bred & $2-36$ months & 22 & 100 & 0
\end{tabular}

\footnotetext{
a The mortality rate considered only piglets.
} 


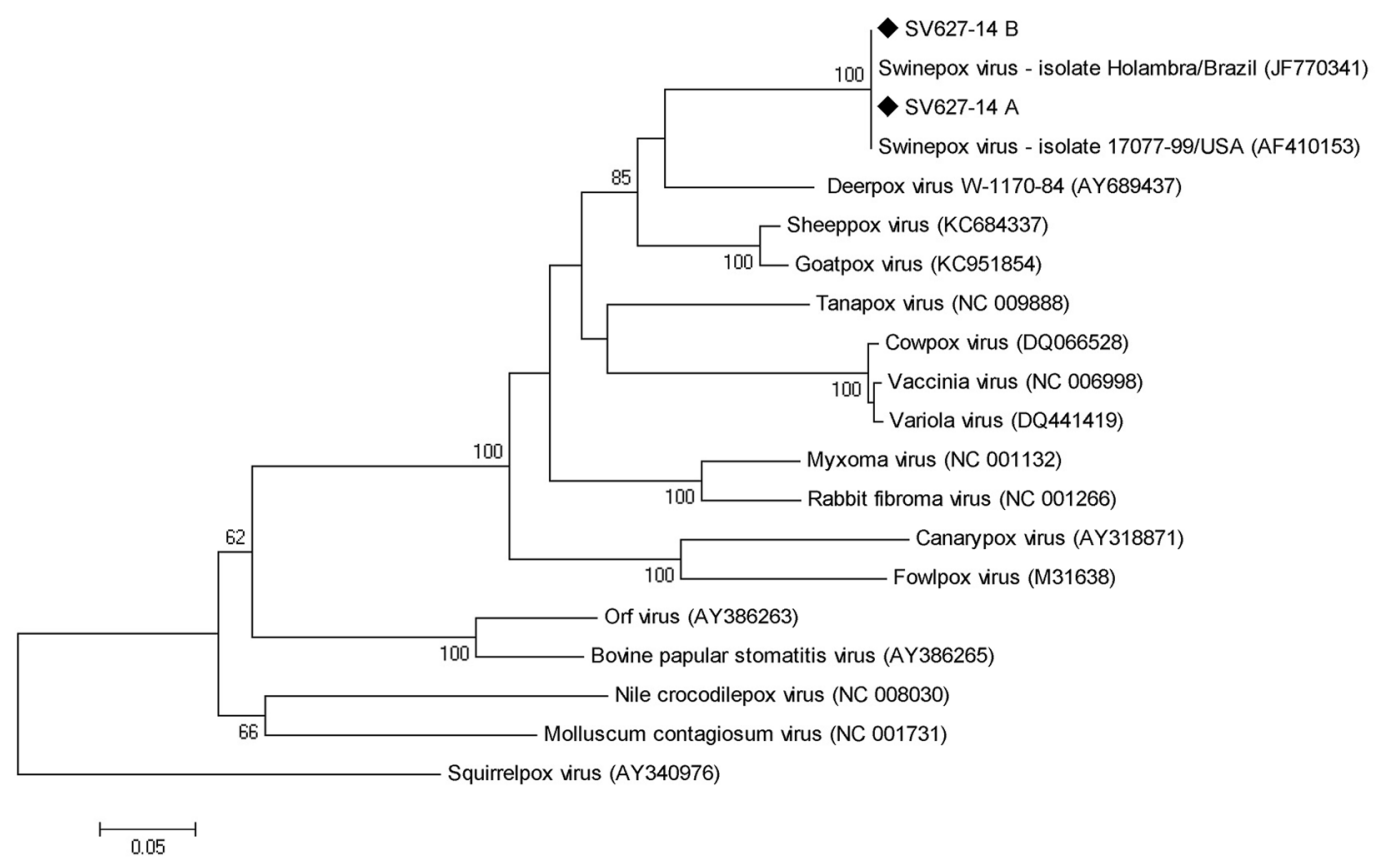

Fig.1. Phylogenetic tree based on the nucleotide sequences of DNA polymerase gene of different genus of Poxviridae family: Avipoxvirus (GenBank access numbers AY318871 and M31638), Capripoxvirus (KC684337 and KC951854), Cervidpoxvirus (AY689437), Crocodylidpoxvirus (NC008030), Leporipoxvirus (NC001132 and NC001266), Molluscipoxvirus (NC001731), Orthopoxvirus (DQ066528, NC006998 and DQ441419), Parapoxvirus (AY386263 and AY386265), Suipoxvirus (JF770341 e AF410153) and Yatapoxvirus (NC009888); the outgroup was composed by the respective gene of Squirrelpoxvirus (AY340976). The tree was constructed using the Neigbohr-Joining method with 1,000 bootstrap replicates based on p-distance model and implemented by MEGA 5.0. Values $>60 \%$ are shown. The swinepox positive sample of the present report is identified with a black diamond.

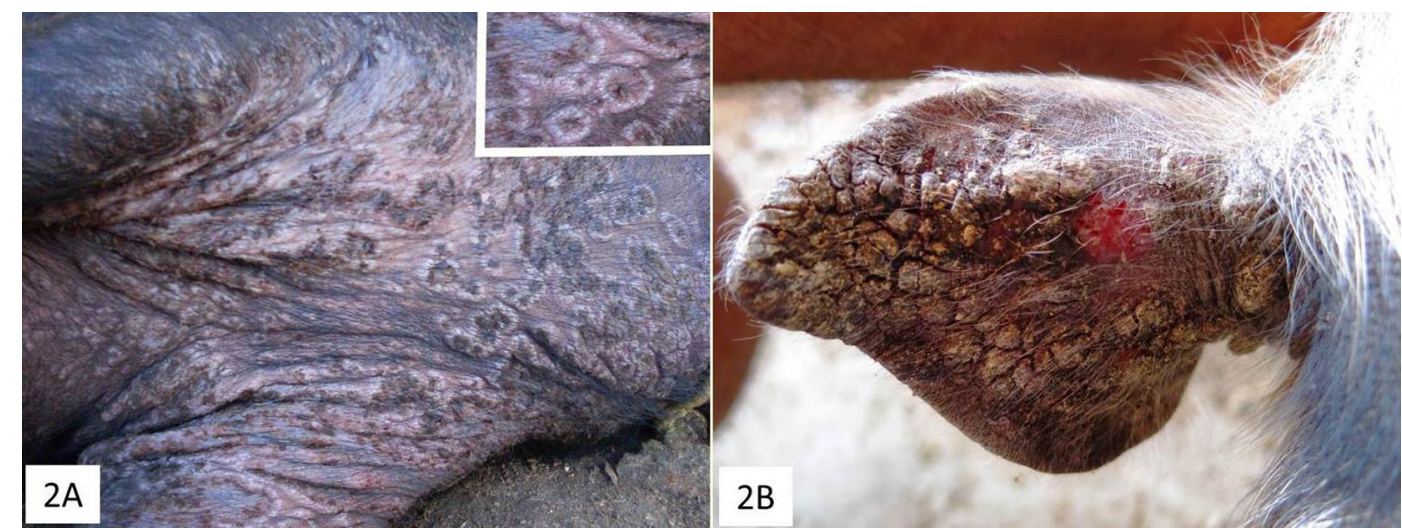

Fig.2. Gross findings with swinepox infection in pigs. (A) Multifocal to coalescing, circular vesicles and papules in the neck and forelimbs.

(B) The pinna is covered with severe crusting.

initially seen in adult pigs and progressively disseminated to the entire herd. Lesions were severe in piglets, especially in outbreaks 2 and 4 (located 1.5 to 2.0 kilometers apart) where farms had poor hygienic conditions and high lice and fly infestations

In most cases, the initial lesions were multifocal to coalescing white to grey papules $(2-10 \mathrm{~mm}$ in diameter) (Fig.2A) and blisters that usually evolved to crusts and scabs with erosions and, in some cases, formation of $3-10 \mathrm{~mm}$ ulcers. Lesions were more severe in the ears (Fig.2B), periorbital region, abdomen and internal face of the limbs and, less extensively, in the dorsal and lateral flanks. The piglets had severe crust formation in the periocular area and palpebrae with subsequent infestation by fly larvae
(Cochliomyia hominivorax) and secondary bacterial infection, causing blindness and deaths. These piglets also presented with apathy, anorexia and fever.

The clinical course of the disease was approximately 15 to 25 days. The morbidity ranged from 33.3 to $100 \%$. Mortality was observed only in piglets of two farms, varying from 55 to $60 \%$ (Table 1).

Histological examination revealed proliferative and ulcerative vesiculopustular dermatitis with ballooning degeneration of epithelial cells, spongiosis, hypergranulosis, parakeratotic or orthokeratotic hyperkeratosis, and acanthosis (Fig.3A). Eosinophilic, rounded, intracytoplasmic inclusion bodies, with $3-8 \mu \mathrm{m}$ in diameter were consistently observed in keratinocytes, mainly in areas of pustule for- 


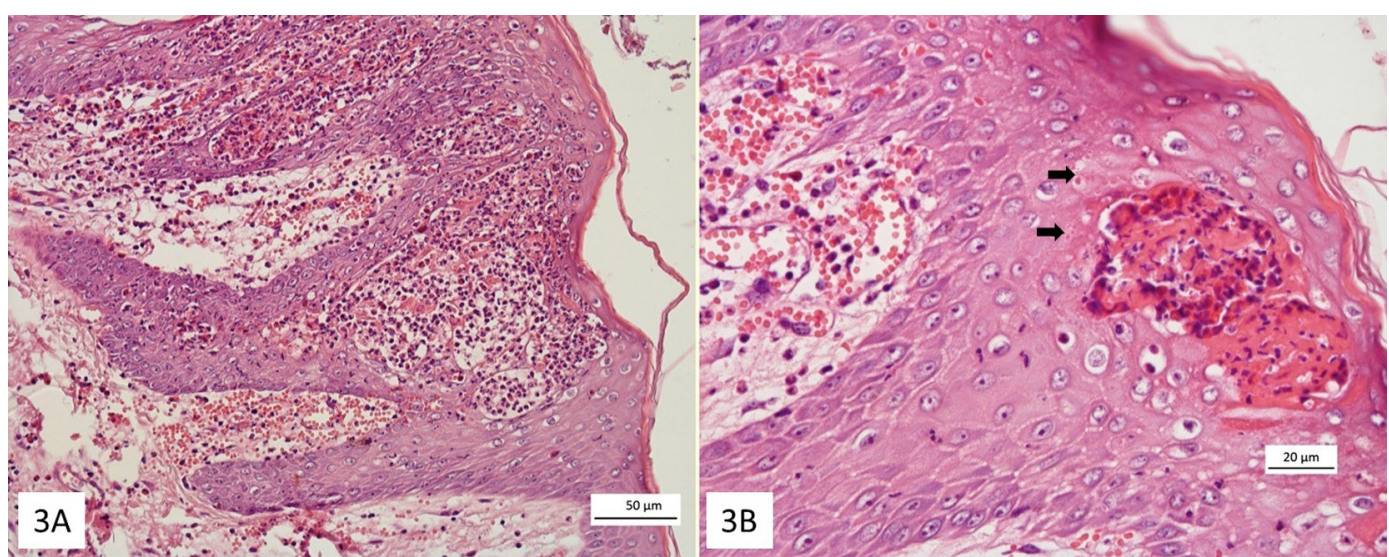

Fig.3. Histologic lesions with swinepox virus infection in pigs. (A) Severe intraepidermal pustular dermatitis HE, Bar=50 $\mu$ m. (B) Rounded, eosinophilic, intracytoplasmic inclusions, with 3-8 $\mu \mathrm{m}$ in diameter (arrows), are observed near a pustule. HE, Bar=20 $\mu \mathrm{m}$.

mation (Fig.3B). Focally extensive and coalescent ulcers were noted. Congestion, hemorrhage and perivascular inflammatory infiltrate of lymphocytes, plasma cells, neutrophils, eosinophils and fewer macrophages were observed in the dermis.

No infectious virus was recovered from tissue samples from outbreak 5 (SV 627/14, samples A and B) after three passages in culture cells. However, a PCR for SWPV performed in DNA extracted from these samples resulted positive, yielding a product of approximately $540 \mathrm{pb}$, corresponding to the size of the amplicon obtained from the positive control (not shown). DNA sequences of SV627/15 A and B samples showed $100 \%$ of nucleotide identity and, then, only one sequence was deposited on Genbank (SVV627/14: accession number KT988005). Nucleotide sequencing of the amplicons from outbreak 5 revealed a $100 \%$ of nucleotide identity between them and with SWPV isolates 1707799 (Nebraska, USA) (Afonso et al. 2002) and Holambra, São Paulo state, Brazil (Medaglia et al. 2011) deposited in GenBank. On the other hand, the nucleotide identity with other poxviruses genus was below $81 \%$.

\section{DISCUSSION}

The amplification of a 541bp fragment of the viral DNA polymerase gene out of material from outbreak 5 definitively confirmed SWPV as the etiologic agent of this outbreak. Phylogenetic analysis demonstrated a close relationship of the identified virus with other SWPV previously reported in Brazil. The identity of nucleotides between samples from outbreak 5 (A and B) and strain SWPV Holambra (Medaglia et al. 2011) was 100\%. The phylogenetic analysis based on the amplified sequences grouped the detected viruses (SV627/14 A e B) together with isolates SWPV 17077-99 and Holambra (Fig. 1), indicating a close genetic relationship and likely a common ancestral. As expected, viruses SV627/14 A and B grouped separately from VACV, an agent to be included in the differential diagnosis of vesicular diseases in pigs (Shope 1940). Since no fresh tissue was available from the other outbreaks, PCR from FFPE tissue was negative. Regardless, the proximity of the outbreaks and the similarity in epidemiological, clinical, and pathological features suggests that the other outbre- aks may have also been associated with SWPV. In any case, immunological and/or molecular means are needed to confirm this hypothesis.

In Brazil, in spite of the swine population (approximately 39,000,000 animals according to Instituto Brasileiro de Geografia e Estatística [http://seriesestatisticas.ibge.gov. $\mathrm{br} /$ series.aspx?vcodigo=PPM01]), widespread distribution of swine herds and diversity of pig farming, ranging from intensive commercial units in the Southern and Southeastern regions to small backyard farming in Northeast and Northern states, only sporadic reports of swinepox have been published. One study described the molecular detection and identification of the virus in pigs herds in Southeastern (Holambra, São Paulo state in 2010 and 2011) (Medaglia et al. 2011). A previous study has reported the occurrence of clinically similar, vesiculopustular dermatitis in pig herds in São Paulo and Tocantins states, yet without the definitive identification of the agent (Bersano et al. 2003). The present study confirms the circulation of SWPV in backyard pig herds in Northeastern Brazil where the disease has not been reported. These outbreaks occurred in 2008, 2013 and 2014 in backyard pigs with a poor sanitary condition, with high lice and fly infestations. SWPV transmission may occur through direct contact among animals yet lice may assume special importance in virus dissemination by causing intense itching and facilitating virus penetration into the skin. In addition, lice may act as mechanic vectors in virus transmission (Munz \& Dumbell 1994, Roehe \& Brito 2012) since the virus may remain viable in the insect proboscides for days, facilitating virus dissemination among animals and between herds (Munz \& Dumbell 1994). Therefore, SWPV infection should be especially considered in the differential diagnosis of skin diseases (dermatitis) in pig herds with high fly and lice infestations. Vaccinia virus (VACV) has also been associated with vesicular disease in swine (Shope 1940). With smallpox eradication and the end of vaccination, the possibility of cases in pigs associated with escape of vaccine virus virtually disappeared (Roehe \& Brito 2012). Nonetheless, VACV infection has been repeatedly reported in several Brazilian states affecting mainly dairy cattle and man (Damaso et al. 2000, Silva-Fernandes et al. 2009, Sant'Ana et al. 2013) but also other 
species such as horses (Brum et al. 2010, Campos et al. 2011), wild rodents and primates (Abrahão et al. 2010b). Thus, VACV should be included in the differential diagnosis of vesicular cutaneous diseases in swine since the lesions caused by SWPV and VACV are virtually identical.

Since, SWPV and VACV produce similar lesions, additional laboratory testing is crucial for the definitive diagnosis. In this case, virus isolation yielded negative results, however tissue fragments obtained from pigs in outbreak 5 were positive for SWPV using PCR.

\section{CONCLUSION}

This paper reports five outbreaks of cutaneous disease in backyard pigs in Northeastern Brazil, indicating the need of including SWPV in the differential diagnosis of dermatitis in pigs.

Acknowledgements.- R.G. Olinda, J.F. Cargnelutti, A.F.M. Dantas, E.F. Flores and F. Riet-Correa are Conselho Nacional de Desenvolvimento Científico e Tecnológico (CNPq) research fellows.

\section{REFERENCES}

Abrahão J.S., Drumond B.P., Trindade G.S., Silva-Fernandes A.T., Ferreira J.M., Alves P.A., Campos R.K., Siqueira L., Bonjardim C.A., Ferreira P.C. \& Kroon E.G. 2010a. Rapid detection of Orthopoxvirus by semi-nested PCR directly from clinical specimens: a useful alternative for routine laboratories. J. Med. Virol. 82:692-699.

Abrahão J.S., Silva-Fernandes A.T., Lima L.S., Campos R.K., Guedes M.I., Cota M.M., Assis F.L., Borges I.A., Souza-Júnior M.F., Lobato Z.I., Bonjar$\operatorname{dim}$ C.A., Ferreira P.C., Trindade G.S. \& Kroon E.G. 2010b. Vaccinia virus infection in monkeys, Brazilian Amazon. Emerg. Infect. Dis. 16:976-979.

Afonso C.L., Tulman E.R., Lu Z., Zsak L., Osorio F.A., Balinsky C., Kutish G.F. \& Rocha D.L. 2002. The genome of swinepox virus. J. Virol. 76:783-790.

Bersano J.G., Catroxo M.H.B., Villalobos E.M.C., Leme M.C.M., Martins A.M.C.R.P.F., Peixoto Z.M.P., Portugal M.A.S.C., Monteiro R.M., Ogata R.A. \& Curi N.A. 2003. Varíola suína: estudo sobre a ocorrência de surtos nos estados de São Paulo e Tocantins, Brasil. Arq. Inst. Biológico, São Paulo, 70:269-278.

Bracht A.J., Brudek R.L., Ewing R.Y., Manire C.A., Burek K.A., Rosa C., Beckmen K.B., Maruniak J.E. \& Romero C.H. 2006. Genetic identification of novel poxviruses of cetaceans and pinnipeds. Arch. Virol. 151:423-438.
Brum M.C.S., Anjos B.L., Nogueira C.E.W, Amaral L.A., Weiblen R. \& Flores E.F. 2010. An outbreak of orthopoxvirus-associated disease in horses in southern Brazil. J. Vet. Diagn. Invest. 22:143-147.

Campos R.K., Brum M.C.S., Nogueira C.E.W., Drumond B.P., Alves P.A., Siqueira-Lima L., Assis F.L., Trindade G.S., Bonjardim C.A., Ferreira P.C., Weiblen R., Flores E.F., Kroon E.G. \& Abrahão J.S. 2011. Assessing the variability of Brazilian Vaccinia virus isolates from a horse exanthematic lesion: coinfection with distinct viruses. Arch. Virol. 156:275-283.

Cargnelutti J.F., Santos B.S., Lebre S.D., Sodré D.N.A., Silva R.M., Weiblen R. \& Flores E.F. 2014. Pseudocowpox and papular stomatitis in cattle in the Rondonia state, Brazil. Ciência Rural 44:479-485.

Damaso C.R.A., Esposito J.J., Condit R.C. \& Moussatche N. 2000. An emergent poxvirus from humans and cattle in Rio de Janeiro State: Cantagalo virus may derive from Brazilian smallpox vaccine. Virology 277:439-449.

Delhon G.A., Tulman E.R., Afonso C.L. \& Rock D.L. 2007. Genus Suipoxvirus, p.203-215. In: Mercer A.A., Schmidt A. \& Weber O. (Eds), Poxviruses. Birkhauser Verlag, Berlin.

Jubb T.F., Ellis T.M., Peet R.L. \& Parkinson J. 1992. Swinepox in pigs in Northern Western-Australia. Aust. Vet. J. 69:99-99.

Medaglia M.L.G., Pereira A.D., Freitas T.R.P. \& Damaso C.R. 2011. Swinepox virus outbreak, Brazil. Emerg. Infect. Dis. 17:1976-1978.

Munz E. \& Dumbell K. 1994. Swinepox, p.627-629. In: Coetzer J.A.W., Thomson G.R. \& Tustin R.C. (Eds), Infectious Diseases of Livestock. Oxford University Press, New York.

Paton D.J., Brown I.H. \& Fitton J. 1990. Congenital pig pox: a case report. Vet. Rec. 127:204.

Roehe P.M. \& Brito W.D. 2012. Varíola, p.409-411. In: Sobestiansky J. \& Barcellos D. (Eds), Doenças de Suínos. Cânone Editorial, Goiânia.

Sant'Ana F.J.F., Leal A.D., Rabelo R.E., Vulcani V.A.S., Ferreira Junior J.A., Cargnelutti J.F. \& Flores E.F. 2013. Outbreaks of vesicular disease caused by Vaccinia virus in dairy cattle from Goias State, Brazil (2010-2012). Pesq. Vet. Bras. 33:860-866.

Schwarte L.H. \& Biester H.E. 1941. Pox in swine. Am. J. Vet. Res. 2:136-140. Shope R.E. 1940. Swine pox. Archiv für die gesamte Virusforschung 1:457-467.

Silva-Fernandes A.T., Travassos C.E.P.F., Ferreira J.M.S., Abrahão J.S., Rocha E.S., Viana-Ferreira F., Santos J.R., Bonjardim C.A., Ferreira P.C. \& Kroon E.G. 2009. Natural human infections with Vaccinia virus during bovine vaccinia outbreaks. J. Clin. Virol. 44:308-313.

Staden R. 1996. The Staden sequence analysis package. Mol. Biotechnol. 5:233-241.

Tamura K., Peterson D., Peterson N., Stecher G., Nei M. \& Kumar S. 2011. MEGA5: Molecular evolutionary genetics analysis using maximum likelihood, evolutionary distance, and maximum parsimony methods. Mol. Biol. Evol. 28:2731-2739. 